\title{
The Action of Natural Waters on Lead.
}

\author{
By JOHN C. THRESH, M.D., D.Sc., F.I.C.
}

(Concluded from p. 468.)

\section{Part II. The Action of Moorland Waters on Lead.}

THE results obtained by experiments made with solutions of single salts in distilled water demonstrated that the presence or variation in quantity of any one of these could not explain the results obtained from different waters, but that the silicates, carbonates, sulphates and salts of some organic acids, together with this organic acid and free carbonic acid, were the constituents which by their varying quantity might cause the differences observed.

Characteristics of Moorland Waters. In moorland waters containing only a few mgrms. of solid matter in solution in 100 c.c. the carbonates present would have no appreciable effect in preventing the oxidation of lead, but a very insoluble lead carbonate might be formed, and, in the absence of appreciable quantities of carbonic or citric (?) acid, practically no lead might remain in solution. An alkaline silicate, on the other hand, would markedly retard or prevent the solution of the lead, and form on the metal an even more difficultly soluble lead compound. Acids like citric, and their salts, however, dissolve a small quantity of the lead, but the salts not so much as would an equivalent quantity of free acid. The only action of sulphates seems to be a coagulative one, the calcium and magnesium salts being more active than sodium sulphate, in precipitating the lead compounds formed when the water has become alkaline from solution of lead oxide.

The organic acids which are recorded as having been found in infusions of bilberry, of heather and of bog-moss, are citric, malic, quinic, acetic, and benzoic; infusions of these plants act on lead as does citric acid. Quinic acid has a somewhat similar effect to citric, but apparently acetic, malic and benzoic acids, unless in a free state, have no special action.

In the experiments to be recorded the organic matter in the imitation waters made was in all cases citric acid, and this not in excess of what might be found in the water imitated. Before this investigation had been commenced all attempts to make an imitation of a natural moorland water, which should have the same electric conductivity, hydrogen ion concentration, and action on lead, were utter failures, and the chief object of the investigation was to enable me to make reasonably accurate imitations. This has been fairly well accomplished, as the following results show.

In the final Table (p. 504) will be found a record of over 40 moorland waters from various parts of the kingdom arranged in order of the extent with which the waters oxidised the lead foil inserted therein in 24 hours, the waters giving up the minimum quantity of oxygen being placed first. It will be noted that the physical and chemical examinations do not permit of any opinion being expressed 
upon the action of the waters on lead, but it seems quite probable that, if the organic acid and silica were also determined, the extent of this action could be predicted. The most surprising result of the examination of these waters was the large proportion which had no apparent action, beyond a slight dulling of the surface of the lead foil. That the largest proportion gave up less than 50 per cent. of the dissolved oxygen in the $\mathbf{2 4}$ hours, may be due to the fact that most of the samples came from Derbyshire, but it is worthy of mention that not a single sample giving up more than 50 per cent. of the oxygen came from that county. This suggests that the geological characteristics of the gathering ground, or the nature of the plants growing thereon, or both, have a marked influence on the character of the water collected.

Natural Waters and their Imitations.-The Table on p. 502 gives examples of the characteristics of five waters imitated.

The first 25 samples gave up less than 25 per cent. of their dissolved oxygen, and all came from the moors around Glossop in North Derbyshire, with the exception of No. 11, which was from Lake Wyrney, as supplying Liverpool.

In the case of the imitations of waters No. 1 and No. 11 small differences in the amounts of citric acid and of silica markedly affected the action on lead.

The next eight waters yielded over 25 per cent., but less than 50 per cent. of their dissolved oxygen to the lead foil immersed therein. Five came from the Derbyshire moors, No. 30 from Lancashire, No. 27 from Durham, and No. 23 from South Wales. No. 32 was fairly closely imitated, as shown in the table; no doubt a slight increase in the silicate would have given a nearer approach, but the electric conductivity would then have been too high.

Waters Nos. 34 to 42 inclusive gave up more than 50 per cent. of their dissolved oxygen to the lead foil, and it is noteworthy that not a single one of these came from Derbyshire, that only one contained more than a trace of silica, and that only one contained any free acid other than carbonic. No. 35 was from a Wakefield reservoir, Nos. 34, 37, 39, and 41 came from Dartmoor, 36 from Wales, 40 from Cumberland, 42 from Loch Katrine, and 38 from Durham. The imitations of two of these (Nos. 36 and 42 ) are recorded above.

No nearer approach could be made to the Welsh lake water (No. 36). Apparently the organic colouring matter had some effect, increasing the electric conductivity and retarding oxidation. This water was much more highly coloured than any other sample of water examined.

Loch Katrine water (No. 42) is typical of the waters which oxidise lead freely, and it is significant that such waters do not necessarily have a prolonged action on lead pipe. The two waters examined which acted most vigorously on lead were No. 40 (Cumberland lake supply) and this No. 42 (Loch Katrine). Samples were examined which had stood all night in domestic supply pipes, one from a house over 20 years old, and another from a house only recently erected, yet both were practically free from lead. Experiments now being made indicate that meaning is due to some colloid derived from heather, bilberry, or possibly from bog-moss, and more cannot be said at present. 


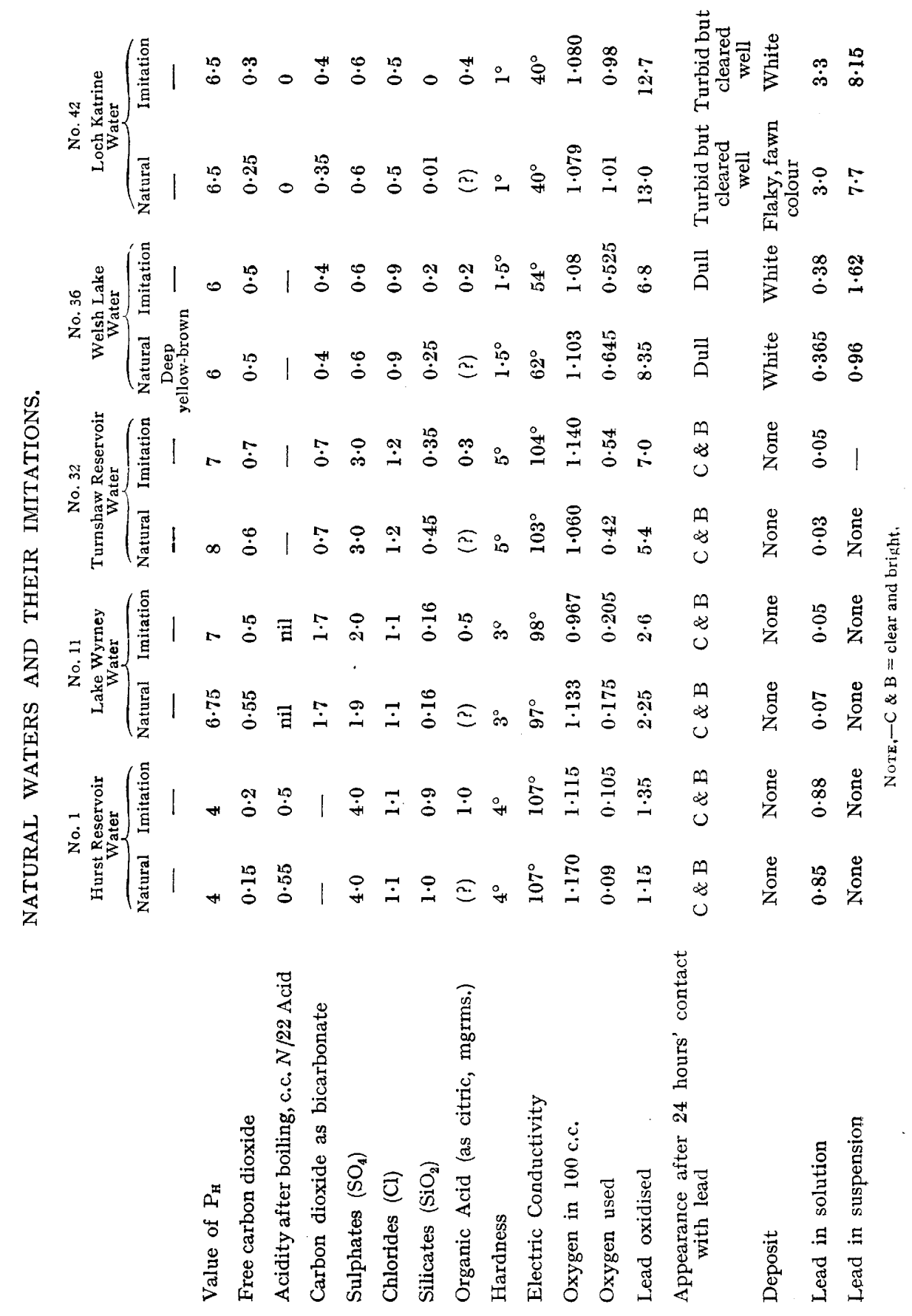


In the Loch Katrine water there is very little silica, but an appreciable amount of organic matter, containing a salt of an organic acid, apparently citric acid. In imitating this water it was not necessary to use any silica.

So far no water has been met with which could not be very closely imitated.

Use of Silica in Practice.-The silicate may prove to be even more important than is here indicated, since it not only tends to prevent the oxidation of lead, but also of iron and aluminium. It was suggested to a water authority deriving water from moorlands, that the action of the water on lead could be prevented by the use of a sodium silicate. This water acted not only on lead, but also upon iron. The water was continuously turbid, as delivered to the consumers, and great expense was incurred in flushing and scraping the mains. The water, after treatment with silicate, ceased to act on lead, and in a few days the water delivered in the town became free from colour and was described as "brilliant." When the mains were flushed, to the surprise of the men, there was no iron oxide to wash away. The effect could only be described as marvellous. If it continues, further details will be published.

Sodium silicate is very cheap, and being in liquid form, is easily diluted and the dose regulated. Its great advantage is that it decreases the oxidation of the lead and forms a very insoluble coating on the metal, whereas carbonates have very little effect upon the oxidation, produce a more easily dissolved deposit, and frequently some of this is suspended in the water and carried forward when the velocity of the current is increased. Lime, in the absence of a silicate in the water, has apparently very little effect.

OTHER WATERS.-A few words may be said about certain other waters recently examined, because they were used for domestic purposes and were suspected of causing plumbism. The amounts, in some cases, were too small for any extended examination. No. 44 was interesting because the lead was traced to the friction of the pump piston on the lead pump barrel. The water itself did not dissolve any lead. It is doubtful, also, whether No. 43 was dangerous. In Nos. 45, 46 and 47 the free carbonic acid was responsible for the action, but in Nos. $48 a$ and $b$ there was a non-volatile acid present. They came from the same well, which supplied a workman's cottage on a sewage farm. No. $48 a$ was the first sample examined, $48 \mathrm{~b}$ a sample sent after the well had been emptied once or twice and cleansed. It is the only water examined in which the acid present seemed to be "inorganic." It was loaded with nitrates, and, when evaporated, gave off red fumes before becoming dry.

There are three gentlemen to whom I should like to express my indebtedness-Dr. Milligan, Medical Officer of Health, Glossop; Mr. Page, Chief Chemist at the Rothamsted Experimental Station; and my assistant, Mr. Martin, A.I.C., as each has rendered me great assistance. 
ACTION OF MOORLAND WATERS ON LEAD.

Arranged in order of amount of Lead oxidised in 24 hours.

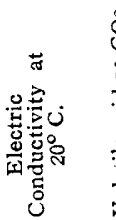

$107 \quad 0.15$

$92 \quad 0 \cdot 15$

$650 \cdot 05$

$\begin{array}{lll}72 & 0 \cdot 1\end{array}$

$\begin{array}{ll}80 & 0 \cdot 1\end{array}$

$90 \quad 0 \cdot 3$

$89 \quad 0.55$

$109 \quad 0.45$

$\begin{array}{lll}98 & 0.45\end{array}$

$80 \quad 0 \cdot 1$

$97 \quad 0.55$

$\begin{array}{ll}95 & 0.4\end{array}$

$102 \quad 0.3$

1050.15

$\begin{array}{ll}92 & 0.40\end{array}$

$\begin{array}{ll}95 & 0.55\end{array}$

$106 \quad 0.3$

$110 \quad 0.5$

$1510 \cdot 1$

$106 \quad 0.6$

$95 \quad 0.15$

$109 \quad 0.15$

$147 \quad 0 \cdot 3$

$200 \quad 0.15$

$100 \quad 0 \cdot 5$

$106 \quad 0.2$

$86 \quad 0 \cdot 2$

$110 \quad 0 \cdot 3$

- 0.1

$138 \quad 0.5$

$\begin{array}{lll}180 & 0 \cdot 3\end{array}$

- 0.6

$\begin{array}{lll}4.5 & 90 & 4.9\end{array}$

- $0 \cdot 2$

- $\quad 0.2$

$62 \quad 0 \cdot 5$

$70 \quad 0.4$

- 0.2

- 0.1

$\begin{array}{ll}38 & 0.25\end{array}$

$41 \quad 0.2$
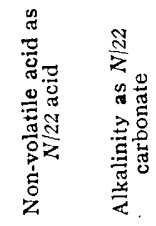

$\begin{array}{llll}0.55 & 0.0 & 3.0 & 1.0\end{array}$

$0.0 \quad 0 \cdot 3$

$\begin{array}{llll}0.0 & 0.1 & 2 \cdot 0 & -\end{array}$

$0.0 \quad 0.15$

$0.0 \quad 0.15$

$0 \cdot 0$

$\begin{array}{lll}0.0 & 0.25\end{array}$

$0 \cdot 2$

$0 \cdot 1$
$0 \cdot 0$

$\begin{array}{llll}0.0 & 0.85 & 1.9 & 0.16 \\ 0.1 & 0.0 & 4 & \end{array}$

$\begin{array}{lllll}0.1 & 0.0 & 4 & - & \\ 0.3 & 0.0 & 2 & -\end{array}$

$\begin{array}{llll}0.3 & 0.0 & 2 & - \\ 0.0 & 0.25 & 4 & -\end{array}$

$\begin{array}{llll}0.0 & 0.3 & 2.9 & - \\ 0.0 & 0.25 & 3.7 & -\end{array}$

$\begin{array}{llll}0.0 & 0.25 & 3.7 & - \\ 0.4 & 0.0 & 3.2 & -\end{array}$

$0 \cdot 0$

$\begin{array}{llll}0.0 & 0.5 & - & 0.3\end{array}$

$0 \cdot 0$

0.0

$0 \cdot 0$
$0 \cdot 0$

$0 \cdot 0$
$0 \cdot 0$

$0 \cdot 0$

$0 \cdot 5$

$0 \cdot 0$

$0 \cdot 0$
$0 \cdot 0$

$0 \cdot 0$
$0 \cdot 0$

$0 \cdot 0$

$0 \cdot 0$

$0 \cdot 0$

$0 \cdot 0$

$1 \cdot 5$
$0 \cdot 0$

$0 \cdot 0$

$0 \cdot 0$
$0 \cdot 0$

$0 \cdot 0$

$0 \cdot 0$

$0 \cdot 0$
$0 \cdot 0$

$0.75 \quad-\quad 0.6$

$0.15 \quad 3 \quad$ -

$\begin{array}{lll}0.3 & 1 & 0.04\end{array}$

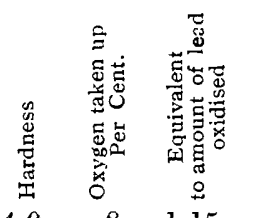

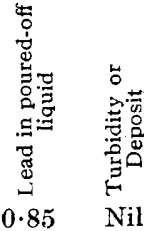

$\begin{array}{lllll}3 \cdot 5 & 10 & 1.45 & 0.55 & \mathrm{Nil}\end{array}$

$\begin{array}{lllll}2^{\circ} & 10 & 1.4 & 0 \cdot 10 & \text { Nil }\end{array}$

$\begin{array}{lllll}2 \cdot 5 & 10 & 1 \cdot 6 & 0.13 & \text { Nil }\end{array}$

$\begin{array}{lllll}2 \cdot 5 & 10 & 1.6 & 0 \cdot 10 & \mathrm{Nil}\end{array}$

$\begin{array}{lllll}3 & 10 & 1.3 & 0.76 & \text { Nil }\end{array}$

$\begin{array}{lllll}3 \cdot 5 & 11 & 1 \cdot 6 & 0 \cdot 60 & \mathrm{Nil}\end{array}$

$\begin{array}{lllll}3.5 & 14 & 2 \cdot 05 & 0 \cdot 60 & \text { Nil }\end{array}$

$\begin{array}{lllll}3 & 14 & 1.4 & 0.40 & \text { Nil }\end{array}$

$\begin{array}{llll}2 \cdot 5 & 15 & 1.4 & 0 \cdot 10\end{array}$

$\begin{array}{lllll}3 \cdot 5 & 15 & \mathbf{2} \cdot 25 & 0.07 & \text { Nil }\end{array}$

$\begin{array}{lllll}2 \cdot 8 & 16 & 2 \cdot 25 & 0 \cdot 34 & \text { Nil }\end{array}$

$\begin{array}{lllll}3 & 16 & 2.45 & 0.66 & \mathrm{Nil}\end{array}$

$\begin{array}{lllll}3.5 & 17 & 2.5 & 0.22 & \text { Nil }\end{array}$

$\begin{array}{lllll}3 & 17 & 2.5 & 0.62 & \text { Nil }\end{array}$

$\begin{array}{lllll}3.5 & 17 & 2.45 & 0.87 & \text { Trace }\end{array}$

$\begin{array}{lllll}3 & 17 & 2.5 & 0.68 & \text { Trace }\end{array}$

$\begin{array}{lllll}3 & 17 & 2 \cdot 5 & 0 \cdot 68 & \text { Til } \\ 4 & 19 & 2 \cdot 65 & 0.27 & \text { Nil }\end{array}$

$\begin{array}{lllll}5 \frac{1}{2} & 20 & 2.4 & 0.05 & \text { Nil }\end{array}$

$\begin{array}{lllll}3.5 & 20 & 2.85 & 0.93 & \text { Trace }\end{array}$

$\begin{array}{llllll}0.2 & 3.4 & - & 3.5 & 20 & 2 \cdot 85\end{array}$

$\begin{array}{llllll}0.3 & 3 \cdot 1 & - & 3.5 & 21 & 3.15\end{array}$

$\begin{array}{llllll}0.55 & 3 & - & 4 & 22 & 3 \cdot 3\end{array}$

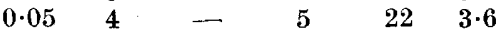

0.554 ? - $\quad-\quad 2436$

$\begin{array}{lllll}0.05 & 3 & - & 3 & 24 \\ 0 & 3.5\end{array}$

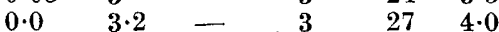

$\begin{array}{lll}3 \cdot 5 & 27 & \mathbf{3} \cdot 5 \\ 3 & 28 & \mathbf{4} \cdot 15\end{array}$

$\begin{array}{lll}3 & 29 & 4 \cdot 1\end{array}$

$3 \cdot 5 \quad 31 \quad 4 \cdot 5$

$\begin{array}{llllll}0 \cdot 15 & 4 \cdot 0 & - & 6 \cdot 5 & 39 & 5 \cdot 7 \\ 0.35 & 3 & 0.45 & 5 & 40 & 5 \cdot 4\end{array}$

$\begin{array}{llllll}0.55 & 3 & 0.45 & 5 & 40 & 5.4 \\ 0.8 & - & - & 46 & 5.5\end{array}$

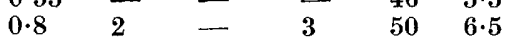

$\begin{array}{llllll}0 \cdot 0 & 2 & - & 3 & 54 & \mathbf{7} \cdot 2\end{array}$

$\begin{array}{llllll}0.2 & 0.6 & 0.2 & 1.5 & 58 & 8.35\end{array}$

$\begin{array}{llllll}0.15 & 0.8 & - & 0.5 & 60 & 7.75\end{array}$

$\begin{array}{llllll}0.25 & 0.8 & 0.4 & 1.5 & 61 & 7.9\end{array}$

$0.45 \quad-\quad-\quad 71 \quad 8.65$

$\begin{array}{llllll}0.3 & 0.1 & - & 1.5 & 73 & 9.4\end{array}$

$\begin{array}{lll}0.15 & 0.6 & 0.01\end{array}$

$0 \cdot 5$

80
90

Rain Water from Underground Tanks.

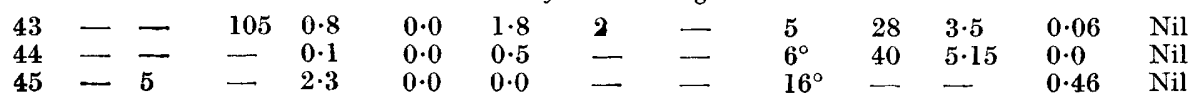

Well Waters Suspected of Causing Plumbism.

\begin{tabular}{|c|c|c|c|c|c|c|c|c|c|c|c|}
\hline- & 5 & - & $7 \cdot 2$ & 0.0 & 0.4 & $8 \cdot 1$ & - & 15 & 44 & $5 \cdot 15$ & $2 \cdot 05$ \\
\hline 47 & 6 & - & $2 \cdot 1$ & $0 \cdot 1$ & 0.0 & $5 \cdot 5$ & - & 7 & - & - & $0 \cdot 60$ \\
\hline $48 a$ & 3.5 & 988 & $3 \cdot 1$ & $4 \cdot 6$ & $0 \cdot 0$ & 20 & - & 28 & 20 & $2 \cdot 6$ & $2 \cdot 8$ \\
\hline $48 b-$ & $4 \cdot 5$ & - & $2 \cdot 4$ & $2 \cdot 4$ & 0.0 & 20 & - & 28 & 11 & $1 \cdot 3$ & 0.9 \\
\hline
\end{tabular}

Nore. $-S$ represents surface water; $R$ reservoir water; and $L$ lake water. 


\section{Discussion.}

Mr. RAyMond Ross said that he was extremely interested in the author's paper, more especially as it dealt with moorland waters, and referred to two reservoirs in his (the speaker's) district, the water from one of which did not act, and never had acted, on lead, whereas the other (although only a mile distant) acted strongly on lead at all times of the year. He doubted whether this was caused by smoke carried by the wind, which he was much interested to hear could have this effect on the water. He would like to know if the author could give an explanation of the difference between these two waters. At one time the water had been treated with chalk, but this very soon blocked up the sand filters, and the treatment was discarded as ineffective. The water had then been treated with aluminium sulphate and lime (leaving the water just acid), followed by filtration through mechanical filters and the addition of clear lime water controlled by means of Venturi meters, and no lead had been found in water treated by this method. It had been found that if too much lime were added before filtration (so that the water had an alkaline reaction) dirt was extracted from the filters. They had never had lead poisoning in the district since this method of filtration had been employed.

Mr. E. M. HAwkins said that he had found in practice that rain water stored in tanks, made merely by digging $20 \mathrm{ft}$. down into clay cementing, never acted on lead, and he enquired whether that was due to silicate in the water.

Mr. R. L. ColletT asked whether Dr. Thresh had experimented with different kinds of lead, or lead which had been soldered; or whether the presence of air had an influence on the action of water on lead.

Dr. A. F. JOSEPH instanced the case of a farmer (being treated medically for rheumatism) who was really suffering from lead poisoning, the water on his farm (when analysed) being found to contain 15 grains of lead per gallon.

Dr. THRESH, in replying to Mr. Raymond Ross, said that the difference was due to the amount of silicate in the water; he had found the same thing in water from certain parts of Yorkshire. As regards Mr. Hawkins' question, tank water would contain a fair amount of carbonate of lime; few well waters were free from carbonates. With reference to Mr. Collett's enquiries, he had used assay lead foil in most of his experiments, but had carried out some with pure lead sheet of 99.99 per cent. purity, from Newcastle.

As regards lead poisoning, there were probably numbers of cases not recognised. In certain experiments he had taken samples of water where the pressure was $100-\mathrm{ft}$. and from the same main where the pressure was $600-\mathrm{ft}$., and in order to get comparable results he had had the main tapped in the morning, at noon, and again at night. In the morning the sample might contain a distinct amount of lead, at noon nothing, and at night only a very small trace. When the pressure was highest he had found the most lead present. Morning samples alone gave concordant results.

Errata in Part I.-Page 459 last par. The signs +and-should be transposed.

Page 463, 9th line from bottom. For " and in the process " read "it." Page 468, 5th line from end. For "and" read "in." 